\title{
Elementary school in the conditions of digital transformation of the education system
}

\author{
${\text { Lyudmila } \text { Bosova }^{1 *} \text {, Aleksandr Chekin }}^{1}$, Yelena Borisova ${ }^{1}$, Marina Oleynikova ${ }^{1}$, and \\ Aleksandr Fedosov ${ }^{1,2}$ \\ ${ }^{1}$ Moscow Pedagogical State University, Moscow, Russia \\ ${ }^{2}$ Russian State Social University, Moscow, Russia
}

\begin{abstract}
Informational support of education is an area of pedagogical science that has been actively developing in Russia over the past few decades. Today, it has become the basis for the digital transformation of education, whose essence is transforming the methods of professional teaching by integrating digital technologies and moving to a data-based decision-making model. Among the participants of educational relations, there are diametrically opposite views on the possibility and feasibility of digitalization of education, especially at its initial stage. The purpose of this research is to present an authorial standpoint on the problem of digitalization of education with regard to both elementary general education in general, and digitalization of the Mathematics and Computer Science subject area, in particular, at the level of primary general education. The research methods include content analysis of scientific articles and methodological publications, the regulatory framework of school education, as well as generalization and systematization of international research in the field of the digital transformation of education. Authors considered external aspects of the digital transformation of primary education, determined by the general requirements for the information educational environment; highlighted activity areas related to the formation of students' basic digital skills in the course of mastering all subject areas without exception; as well as revealed the problems of internal digitalization of the Mathematics and Computer Science subject area at the level of primary general education. The article substantiates the expediency of strengthening the logical and algorithmic components of the initial course of mathematics, the content line responsible for working with data, as well as several other issues related to theoretical computer science, and outlines prospects of the digital transformation of training of future primary school teachers to work in a modern digital educational environment.

Keywords: digital transformation of education, primary education, Mathematics and Computer Science subject area, elements of theoretical computer science.
\end{abstract}

\footnotetext{
*Corresponding author: 11.bosova@mpgu.su
} 


\section{Introduction}

A characteristic feature of the present time is the digital transformation of all aspects of people's life. The transformation of professional practices through the integration of digital technologies and the transition to a data-based decision-making model take place both in the industrial and social spheres, including science and education. The main areas of the digital transformation of general education in Russia are stated at the federal level in the framework of the Digital Educational Environment Project [1], which provides for automation of document flow, integration of digital technologies into the learning process with access to individual educational trajectories, continuous professional development of teachers, and several other activities. Such a powerful project is a practical implementation and logical continuation of a wide range of research in the field of informatization of education (I.V. Robert, A.L. Semenov, A.Yu. Uvarov, and others).

Digital opportunities in school education cover the widest possible range of areas, providing innovative management and pedagogical solutions to many existing problems [2]. At that, the views of participants in educational relations on the possibility and feasibility of integrating digital technologies into educational activities differ significantly. Different views exist on how the digitization of primary schools should be carried out [3]: opinions on this issue range from the complete rejection of the use of digital technologies to the exclusion of teachers from the educational process substituting the teacher with the robot (a well-known experience of the Finnish and Korean schools, where robot teacher was entrusted with the training of younger pupils). The purpose of this research is to present an authorial standpoint on the problem of digitalization of education with regard to both elementary general education in general, and digitalization of the Mathematics and Computer Science subject area, in particular, at the level of primary general education.

\section{Methods}

The research methods include content analysis of scientific articles and methodological publications, the regulatory framework of school education, as well as generalization and systematization of international research in the field of the digital transformation of education.

\section{Results and discussion}

\subsection{External digitalization}

Let's start with issues that are referred to as external digitalization, that is, issues that are not directly related to the training subject matter. First of all, these are issues of universal provision of schools with access to high-speed Internet, which require serious financial investments. This problem is being solved at the state level and will be solved in the future. An important part of the digital educational environment is educational content presented in a digital format. Translating educational materials into digital format is a task that is well known to domestic developers [4]. Various digital educational resources were created within the framework of many federal and regional projects, such as developed electronic applications and electronic forms of textbooks, and many functioning online educational platforms (Uchi.ru, Yandex.Textbook, YaKlass, etc.). Thus, the Russian Electronic School project contains complete sets of digital lessons from the best teachers in Russia in all subjects studied in primary school. So, today, both teachers and students have a real opportunity to access a variety of collections of digital educational resources, effectively 
integrating them into the educational process. However, in primary school, one cannot imagine successful learning without personal interaction between the teacher and the pupil carried out in person rather than in the online learning format. And this is not just a tribute to tradition: the computer cannot replace the teacher, educational activities, and educational interaction organized by the teacher in a full-time format.

\subsection{Internal digitalization}

While not supporting the simple replacement of traditional practices with their digital counterparts, and moreover, the widespread rejection of traditional practices that have developed over many decades and today form the basis of Russian primary schools, the authors consider it necessary to build modern primary education taking into account the challenges of the contemporary world and the rapidly developing digital environment of today's man. One of the fundamental requirements of the Federal State Educational Standard (FSES) of Primary General Education is "education and development of personal qualities that meet the requirements of the information society and innovative economy" $[5]$.

The range of tasks that today are being solved at the level of primary general education is fundamentally broader than the orientation to the teaching of the basics of literacy or reading, writing, and numeracy skills, although exactly these skills were strongly associated with the tasks of primary school in the population about ten years ago. As for the concept of very literacy, it has been significantly enriched in the $21^{\text {st }}$ century by adapting to new technological conditions, i.e. the digital environment of modern humans. Computers, which became dominant in all spheres of human activity, contributed to the emergence of the concept of computer literacy, which presupposed the possession of basic knowledge, skills, and abilities related to working with a computer. Information literacy is a broader concept, interpreted as the ability of a person to work with information in general. To avoid substitution of concepts, an integral concept of computer and information literacy is introduced as the ability of a person to effectively use computers for research, production, and communication at home, at school, in the workplace, and in society [6]. Today, the concept of literacy is considered even more broadly: the skills of reading, writing, and computing, interpreted in the broadest sense, and used among other things in the digital environment, are supplemented by a third component which is the computational and algorithmic component representing "the ability to perceive and create information in formal software programming languages" [7].

The above makes it relevant to address the issues of internal digitalization, which are associated with changes occurring within the subject areas being mastered by schoolchildren, including the content of teaching specific academic subjects and the formation of skills for working in the digital environment on this basis.

While analyzing all subject areas that comprise the modern educational space of elementary school in terms of the learning process digitalization, first of all, it is natural to talk about the subject area of Mathematics and Computer Science, since it explicitly manifests two of the three components of today's literacy, namely mathematical, and computational and algorithmic. This does not mean that other subject areas should be left out of this process. For example, all subject areas should and can take on the problem of developing pupils' basic digital skills to some extent [8]. It would be fundamentally wrong to assign such a duty to just one subject area since one subject area simply cannot withstand such a load without serious losses of its own subject content. However, there is no doubt that exactly the subject area of Mathematics and Computer Science should make the greatest contribution to solving the issues of internal digitalization. 
First of all, one should pay attention to a rather strange circumstance: the subject area of Mathematics and Computer Science is not de jure divided into academic subjects, although de facto in schools, the corresponding academic subjects happen to be. Moreover, mathematics is among the mandatory subjects, which is natural, while computer science is included in the curriculum of grades 1 to 4 only at the expense of the academic hours that the school can manage. It is obvious that this state of affairs does not meet the challenges of the digital transformation of education. How can this situation be changed? The most reasonable solution is to schedule one academic hour a week to teach Computer Science. But where can school find this academic hour? The question is very challenging, but it needs to be solved, and not at the expense of the hours allotted for mathematics.

Another option for organizing the educational process is related to the introduction of an integrated course of Mathematics and Computer Science into the practice of primary schools. It should be noted that this path is followed by several foreign countries that have been paying close attention to teaching computer science to primary school children in the last decade [9]. One example of such integration is presented in the curriculum of Finland [10]. Attempts to create an integrated course of Mathematics and Computer Science for pupils in grades 1 to 4 have been made more than once in Russia [11]. One of the reasons for the lack of interest of teachers in an integrated subject is that with the current schedule of classroom hours, either the time for studying mathematical issues is significantly reduced, or the study of issues related to computer science does not actually occur.

The real step towards the digital transformation of the Mathematics and Computer Science subject area at the level of primary general education, according to the authors, is to strengthen the logical and algorithmic components of the initial course of mathematics, as well as working with data [12]. This means that the content of the course should include issues that would allow for better training of younger pupils in the field that is commonly called theoretical computer science.

For this purpose, the line of Text Problems and Algorithms can be considered as the core content line of primary mathematical education. Indeed, the issues included in this line are aimed at learning how to solve problems being not only arithmetic but also logical and combinatorial. The essence of solving the problem is to find and write the appropriate algorithm, which is required to get the answer [13]. Thus, pupils, solving text problems will learn not only to design the necessary algorithms but also to perform them.

Strengthening the traditional content of primary mathematics education with elements of theoretical computer science fully meets the challenges facing today's primary schools. Thus, the FSES contains a requirement to master "logical actions of comparison, analysis, synthesis, generalization, and classification" [5]. There is also an indication of the need to develop the ability to organize their activities, which consist in the ability to "accept, maintain goals and follow them in educational activities, plan their activities, monitor, and evaluate them, interact with the teacher and peers in the educational process." In the same document the tasks of developing "logical and algorithmic thinking of students" are also included as the main tasks of implementing the content of the Mathematics and Computer Science subject area. It should be noted that all of the above requirements fully correspond to the task of forming computational thinking that is so relevant in the modern high-tech world [14].

Thus, the formation of mathematical and algorithmic literacy in their modern sense, in fact, becomes one of the answers to the problem of compliance of education with "requirements of the information society and innovative economy" set by the FSES, and has become an important area of internal digitalization of the Mathematics and Computer Science subject area at the level of primary education. At that, it is important that preparing the future primary school teacher would also include digital transformation. The first possible step towards this transformation is the inclusion in the curriculum of the bachelor's 
degree of the major "Pedagogical education, Orientation (profile) on Primary education" (44.03.01) of a wide range of disciplines that would provide comprehensive training for teachers to work in a modern digital educational environment. The solution of the tasks facing a modern primary school will be more effective if the training process of a primary school teacher would necessarily include a research component that makes it possible to train a full-fledged research teacher [15]. A Russian primary school teacher, being, as a rule, a multisubject teacher, should be able to receive university training in the field of forming all the components of literacy of their future students, including the formation of reading and writing algorithms in formal languages in younger pupils that the world pedagogical community considers as "the key to the development of human capital in the $21^{\text {st }}$ century" [16].

\section{Conclusion}

Digital transformation of education is a complex and multifaceted process, whose analysis has identified some aspects that have a general character (external digitalization), as well as those related to the features of a particular subject area (internal digitalization). Considering the problem of compliance of education with "requirements of the information society and innovative economy" set by the FSES, it is possible to distinguish activities associated with the formation of students' basic digital skills encountered in the course of development of all subject areas without exception, as well as consider an issue of internal digitization of the Mathematics and Computer Science subject area at the level of primary education.

Strengthening the traditional content of primary mathematical education with elements of theoretical computer science fully meets the challenges facing the national primary school, and is in tune with the global trend of forming students' computational thinking.

An urgent task of the digital transformation of the national education system is the digitalization of primary education, whose internal level includes, among other things, mass training of primary school teachers to teach pupils computer programming.

\section{References}

1. National project "Obrazovanie" [Education]. 2019-2024, passport, goals, tasks. Accessed on: December 16, 2020. [Online]. Available: https://strategy24.ru/rf/education/projects/natsionalnyy-proekt-obrazovanie

2. I.V. Robert, Russian Digital Libraries Journal, 23(1-2), 145-164 (2020). https://doi.org/10.26907/1562-5419-2020-23-1-2-145-164

3. A.Yu. Fedosov, N.P. Khodakova, Sovremennyye problemy informatizatsii nachalnogo obrazovaniya [Modern problems of primary education informatization] (Zebra, Ulyanovsk, 2019)

4. L.L. Bosova, A.Yu. Bosova, N.Ye. Zubchenok, Sozdaniye i ispol'zovaniye elektronnykh obrazovatelnykh resursov dlya obshchego obrazovaniya [Creation and use of electronic educational resources for general education] (Moscow Pedagogical State University, Moscow, 2014)

5. Order of the Ministry of Education and Science of the Russian Federation dated 06.10.2009 No. 373 (as amended on 31.12.2015) "On the approval and implementation of the federal state educational standard for primary general education" (Registered in the Ministry of Justice of the Russian Federation on 22.12.2009 No. 15785). Accessed on: December 18, 2020. [Online]. Available:

http://www.consultant.ru/document/cons_doc_LAW_96801/ 
6. J. Fraillon, J. Ainley, W. Schulz, T. Friedman, D. Duckworth, Preparing for Life in a Digital World. IEA International Computer and Information Literacy Study 2018 International Report (Springer, Cham, 2020)

7. I.D. Frumin, M. S. Dobryakova, K. A. Barannikov, I. M. Remorenko, Key competences and New Literacy: from Slogans to School Reality. Preliminary results of the international report of major trends in the on-going transformation of school education (Higher School of Economics Publishing House, Moscow, 2018)

8. V. S. Katkalo, D. L. Volkov, I. Baranov et al., Obucheniye tsifrovym navykam: globalnyye vyzovy i luchshiye praktiki [Teaching digital skills: global challenges and best practices], Analytical report (Sberbank Corporate University, Moscow, 2018)

9. L.L. Bosova, Informatika i obrazovaniye, 1, 22-32 (2019)

10. Perusopetuksen opetussuunnitelman perusteet 2014. Accessed on: December 16, 2020. [Online]. Available:

http://www.oph.fi/saadokset_ja_ohjeet/opetussuunnitelmien_ja_tutkintojen_perusteet/p erusopetus

11. A.L. Semenov, T.A. Rudchenko, Mathematics and Informatics. 1 class. Textbooknotebook in 5 parts, 1 (Moscow Center For Continuous Mathematical Education, Moscow, 2010)

12. A.L. Chekin, Obucheniye mladshikh shkolnikov matematike s ispolzovaniyem uchebno-metodicheskogo kompleksa "Perspektivnaya nachal'naya shkola" [Teaching mathematics to junior schoolchildren using the educational and methodological package "Perspective primary school" (Moscow Pedagogical State University, Moscow, 2011).

13. A.L. Chekin, Nachalnaya shkola, 1, 100-101 (2009)

14. P. Curzon, P.W. Mcowan, Power of computational thinking: Games, Magic And Puzzles To Help You Become A Computational Thinker (World Scientific Publishing Co., Singapore, 2017)

15. E.V. Borisova, M.A. Oleynikova, Nachalnaya shkola, 11, 79-82 (2015)

16. S.D. Parandekar, Ye. Patarakin, G. Yayla, Obucheniye detey programmirovaniyu: zalog razvitiya chelovecheskogo kapitala $\mathrm{v}$ XXI veke [Teaching children to program: a guarantee of human capital development in the XXI century], A Guide for Russian Educational Legislators and Practitioners (Aleks IP Polikanin A.A., Moscow, 2019) 